\title{
Inclusion of Pharmacoeconomics course in the Undergraduate Pharmacy Education: A Global Trend Review
}

\author{
Dixon Thomas', Kishore Gnana Sam Sundararaj', Arun Shirwaikar ${ }^{1}$, Yen Huei Tarn² \\ ${ }^{1}$ Gulf Medical University, Ajman, UAE \\ ${ }^{2}$ Kaohsiung Medical University, Taiwan
}

\begin{abstract}
Objective: Although pharmacoeconomics was recognized as a sub-discipline of health economics for over 25 years, its diffusion into pharmacy education has been gradual. The purpose of this review was to describe the global trend of inclusion of pharmacoeconomics course in the undergraduate pharmacy education. Methods: Published literatures were searched and information on the inclusion of pharmacoeconomics course in the undergraduate pharmacy curriculum was collected and collated. Pub Med, Google Scholar, and Google databases were used for the search in October and December 2015. Both compulsory and elective pharmaco economic courses in the undergraduate pharmacy curriculum (BS, B. Pharm, Pharm.D) were considered. We have organized and summarized the information by countries and time period. Trends: Out of 13 surveys reviewed, 4 surveys from the US have provided the key baseline for documenting trends in inclusion of pharmacoeconomics course in the pharmacy curriculum. As per a 2011 survey, pharmacoeconomics course was included in almost all colleges/schools of pharmacy in the US. Other than surveys from the US, 6 were conducted or published in the last 3 years. Many of the surveys identified that the contents in pharmaco economic course vary to different extent. Information from many countries was not available, especially in Africa and Asia. Conclusion: The pharmacoeconomics course was very much part of the undergraduate pharmacy programs in the US. Even though the diffusion of pharmacoeconomics course to the rest of the world was slow; it has picked up the pace in this decade. Standardization of pharmacoeconomics education shall be necessary. Further surveys from countries other than the US are required to comprehend the implications of the trend.
\end{abstract}

Key words: Pharmacoeconomics, Pharmacy curriculum, Pharmacy education, Education trend review, Survey, Course

\section{INTRODUCTION}

Pharmacoeconomics has been defined as the description and analysis of the costs of drug therapy to healthcare systems and society. ${ }^{1}$ Pharmacoeconomic evaluations identify, measure, and compare the costs and consequences of health technology products and services. ${ }^{2}$ It is a sub-discipline of health economics for over 25 years. International Society for Pharmacoeconomics and Outcomes Research (ISPOR) has been in operation since 1995 and is the leading professional society in pharmacoeconomics. Learning pharmacoeconomics improve the knowledge, skill, and competence to value pharmaceutical interventions. ${ }^{3}$ Pharmacists are expected to use pharmaco economic evaluations in the selection process of medicines to hospital formulary. ${ }^{4}$ Pharmacoeconomics has patient, provider, payer, and societal perspectives.

Inclusion of pharmacoeconomics course in the undergraduate pharmacy curriculum (BS, B.Pharm, PharmD) is a trend worldwide. ${ }^{5}$ In some countries, PharmD is a post graduate program. Pharmacoeconomics course was either in compulsory or elective mode. To date, to our knowledge no global review was published to compile surveys on inclusion of pharmacoeconomics course in pharmacy education. One of the interesting articles compared topics taught in undergraduate pharmacy edu-
DOI: 10.5530/ijopp.9.3.3

Address for correspondence: Dr. Dixon Thomas, Asst. Professor College of Pharmacy Gulf Medical University Ajman, UAE Post Box: 4184

E-mail: dixon.thomas@gmail. com

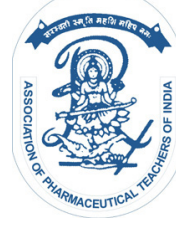

www.ijopp.org 
cation in the US. The researcher commented that the course was taught on par with current pharmacoeconomics literature. ${ }^{6}$ The purpose of this review was to describe the global trend of inclusion of pharmacoeconomics course to pharmacy education.

\section{METHODS}

Published reports were searched and information on inclusion of pharmacoeconomics course in the undergraduate pharmacy curriculum was collected and collated. Pub Med, Google Scholar, and Google databases were used for the search in October and December 2015. Both compulsory and elective pharmaco economic courses in the undergraduate pharmacy curriculum (BS, B.Pharm, PharmD) were considered. We did organize and summarize the information by countries/continent and time period.

\section{TRENDS}

Overall, we found 13 papers with potential information regarding inclusion of pharmaco economic courses in the under graduate pharmacy curriculum. They are listed in chronological order in Table1.

Surveys by Dr. Karen L. Rascati and colleagues provided a key baseline for documenting trends in inclusion of pharmacoeconomics in the US and rest of the world. ${ }^{7}$

Other than surveys from the US, 6 out of 9 were conducted or published in the last 3 years.

\section{US}

A series of surveys conducted by Rascati and colleagues document the gradual adoption of pharmacoeconomics in the US. The most recent survey in 2011 stated that pharmacoeconomics education was provided in almost all US colleges and schools of pharmacy. The survey also found a variation in the number of teaching hours and topics covered in the PharmD curriculum. ${ }^{8}$ In 2008 survey, among the 90 institutions of pharmacy that completed the survey, 7 had no teachers for pharmacoeconomics. ${ }^{9}$ Their earliest survey performed in 1997 showed that sixty-three (80 percent) schools offered pharmacoeconomics education at the BS and/ or PharmD level. ${ }^{10}$

\section{Rest of World Experience by a US study}

Rascati and colleagues carried out a 2004 survey that was aimed to assess the extent of pharmacoeconomics education in colleges outside the US. Ninety colleges and schools from 43 countries responded among which, $52 \%$ of them provided pharmacoeconomics education
(Europe, $\mathrm{n}=19$; Asia, $\mathrm{n}=10$; North America, $\mathrm{n}=7$; Oceania, $\mathrm{n}=6$; and other, $\mathrm{n}=5) .{ }^{11}$

\section{Brazil}

A survey in 2013 observed insufficient pharmacoeconomics education at pharmacy schools in Brazil. Only 16 out of 55 colleges responded. All the 16 colleges agreed the importance of pharmacoeconomics education, but only six schools were providing formal education. $^{12}$

\section{Europe}

A survey was conducted in students of European Pharmaceutical Student Association (EPSA) member associations in 2002. Out of 781 students replied, 63.6\% had insufficient awareness about the term pharmaco economics. Among those who studied pharmacoeconomics in their curriculum, $64.4 \%$ had the subject compulsory and it was optional for the rest. ${ }^{13}$

\section{Turkey}

Pharmacoeconomics was included in the curriculum by two faculties by 2014. The survey conducted in students showed a demand to include pharmacoeconomics in pharmacy curriculum. ${ }^{14}$

\section{Russian Federation}

As per a survey conducted in 2012; $80 \%$ of pharmacy schools in Russian Federation were offering Pharmacoeconomics. The survey was conducted in 47 schools of pharmacy, of which 44 responded; among them 35 were offering pharmacoeconomics. In 26 schools pharmacoeconomics was offered as a required course and in 9 schools, it was an elective course. ${ }^{15}$

In another survey, 13 universities were reviewed in the Ukraine, of which 10 were providing pharmacoeconomics education by 2009. ${ }^{16}$ Another study team observed that by 2013, only one pharmacy school in Bosnia and Herzegovina introduced pharmacoeconomics as a course in undergraduate pharmacy program. ${ }^{17}$

\section{UAE}

In the UAE, five out of seven colleges with B.Pharm and or PharmD programs were providing a pharmacoeconomics course in their curriculum. ${ }^{18-22}$

\section{Egypt}

As per survey to schools of pharmacy in 2013, pharmacoeconomics was not common in the pharmacy curriculum. Only 4 schools offered pharmacoeconomics courses in undergraduate pharmacy education. An additional 8 schools expressed interest in teaching pharmacoeconomics in the near future. The respondents observed 
Table 1: Timeline of surveys published on pharmacoeconomics education.

\begin{tabular}{ccccccccccccc} 
US & Europe & $\begin{array}{c}\text { US study on } \\
\text { rest of the world }\end{array}$ & US & Ukraine & US & $\begin{array}{c}\text { Russian } \\
\text { Federation }\end{array}$ & $\begin{array}{c}\text { Bosnia \& } \\
\text { Herzegovina }\end{array}$ & Brazil & Egypt & Turkey & $\begin{array}{c}\text { Pakistan } \\
\text { Eastern Mediterranean } \\
\text { Region }\end{array}$ \\
1997 & 2002 & 2004 & 2008 & 2009 & 2011 & 2012 & 2013 & 2013 & 2013 & 2014 & 2015 & 2015 \\
\hline
\end{tabular}

a deficiency of well-trained teaching staff in pharmacoeconomics. ${ }^{23}$

\section{India}

All pharmacy schools with PharmD have pharmacoeconomics in their curriculum since $2008 .{ }^{24}$ No formal publication was available on our search about inclusion of pharmacoeconomics course in B.Pharm. Courses vary greatly in B.Pharm than PharmD (relatively new) in India. Even though the basics of pharmacoeconomics were included in some courses of B.Pharm curriculum, it was unusual to be included as a course or a major component in a course.

\section{Pakistan}

Pharmacoeconomics was commonly included in the PharmD program, but the extent of pharmacoeconomics in the curriculum was perceived by senior students as insufficient by a survey in $2015 .{ }^{25}$

\section{Taiwan}

No formal survey was conducted; however, among 8 schools of pharmacy only 3 had the PharmD program. Only 3 schools had a pharmacoeconomics course in the BS and/or PharmD program. ${ }^{26}$

\section{Eastern Mediterranean Region}

A survey in 22 Eastern Mediterranean countries had $41(31 \%)$ responding schools, of which 28 (68\%) from 12 countries were providing pharmacoeconomics education in 2012. There was significant variation in the number of hours and topics covered in pharmacoeconomics. ${ }^{27}$

\section{DISCUSSION}

The US is the forerunner in adoption of pharmacoeconomics training in pharmacy education. Pharmacoeconomics was not common in the pharmacy graduate curriculum before 1990s in the US. This uptake began in the 2000s, but surveys from the US revealed that some schools included pharmacoeconomics in their curriculum only by the last decade. The trend of including pharmacoeconomics in the undergraduate pharmacy curriculum picked up it space even later in the rest of the world. ${ }^{28}$ There are many institutions in different countries that included pharmacoeconomics in this decade. While some institutions were enthusiastic for the future inclusion, the information of inclusion of pharmacoeconomics course was not available from many countries or there were reports of insufficient inclusion. ${ }^{23}$

The possible reasons for inclusion of pharmacoeconomics courses could be three. First, national regulatory requirements of health technology assessment are a major factor. The trend of this inclusion is based on the needs of listing new drugs in the national health insurance program. It was mandatory in many countries that health technology assessment should include pharmacoeconomics study reports. ${ }^{4,29,30}$ Second, promotion of the science of pharmacoeconomics by the International Society for Pharmacoeconomics and Outcomes Research (ISPOR) could be a significant factor leading to inclusion of pharmacoeconomics course in schools of pharmacy. Many countries made national pharmaco economic guidelines, and it was under development in many else. ${ }^{31,32}$ Local and international influences shall contribute to the inclusion of pharmacoeconomics education. Third, the availability of the trained faculty in pharmacoeconomics as another factor in developing countries.

Many health regulators in the world have revised their health technology assessment. ${ }^{31,32}$ For marketing approval, it was focusing on safety and efficacy of newer interventions. However, for listing and reimbursement of new drugs the assessment was focusing on cost-effectiveness and budget impact in addition to comparative quality, safety and efficacy. ${ }^{33}$ As pharmaco economic analyses became part of drug reimbursement and pharmacy practice, the relevance of including pharmacoeconomics in the pharmacy curriculum has become clearer. $^{34}$

\section{Advantages and disadvantages}

The main advantage of including pharmacoeconomics course in graduate pharmacy programs is the production of local pharmacoeconomics expertise. ${ }^{26}$ Pharmaceutical regulation is important in the capacity building. The regulatory transformations happening globally need pharmacoeconomics research as part of health technology assessment. So inclusion of pharmaco economics course is empowering pharmacists to contribute meaningfully to national health policy and healthcare delivery. ${ }^{35}$ Learning pharmacoeconomics has also applications in individual patient care, which is microeconomics. ${ }^{36}$ Healthcare is a cost-sensitive business. ${ }^{37}$ Hospitals 
run with limited resources and many patients face difficulty in paying their healthcare bills. Applying pharmacoeconomics principles in patient care could improve affordability and clinical outcomes. ${ }^{4,38}$ Learning pharmacoeconomics has advantages in improving micro and macro level of healthcare. ${ }^{39}$

Limited access to educational resources is one of the disadvantages in low income countries. ${ }^{35,38}$ The healthcare focuses mainly on cost-minimization rather than costeffectiveness to reduce pharmaceutical expenses. ${ }^{40}$ Even though the resources required for cost-minimization analysis is lesser than other sophisticated analyses, it is advisable to have some level of pharmacoeconomics education in low income countries too.

It is important; of course, that the pharmacoeconomics course content is not poorly planned or implemented. ${ }^{41}$ Major pitfalls in implementation of pharmacoeconomics education were lack of standardization in research, practice, and education. From some of the references cited above; it was evident that in some institutions, the pharmaco economic courses did not meet its course learning objectives. One of the leading reasons for that was lack of expert facilitators.

\section{Guidelines for implementation}

ISPOR is a leading organization that makes good research practice guidelines in pharmacoeconomics research. We could not find any formal guidelines for pharmacoeconomics education. But there are pharmaco economic guidelines on research and practice. The regional pharmaco economic guidelines could be developed by any national agencies or by the university itself. Preferably all teachers of pharmacoeconomics need formal training. They could be involved in pharmacoeconomics research and continuous professional development in collaboration with leading organizations or pharmacy schools. It is important to integrate pharmacoeconomics content to pharmacotherapy textbooks. ${ }^{42}$

\section{CONCLUSION}

In summary, pharmacoeconomics has been included as a course either compulsory or as elective in schools or colleges of pharmacy in many countries. The pharmacy programs we considered in this review were BS, B.Pharm, and or PharmD. Inclusion of pharmacoeconomics course in the undergraduate pharmacy program is a trend in most of the regions except the US. In the US pharmacoeconomics is already a part of the curriculum in the schools/colleges of pharmacy. Universally, many studies suggest that the content in pharmaco economic courses vary to different extent. Information from many other countries with established pharmacy education was lacking. Further surveys from countries other than the US are required to comprehend the implications of the trend.

\section{ACKNOWLEDGEMENT}

We thank Dr. Louis Garrison, Professor, Pharmaceutical Outcomes Research \& Policy Program, University of Washington School of Pharmacy, United States for his valuable suggestions in this review.

\section{CONFLICT OF INTEREST}

Authors Dixon Thomas and Yen Huei Tarn are having affiliations to ISPOR. No conflicts of interest reported.

\section{ABBREVIATION USED}

\author{
BS; Bachelors of Science \\ B.Pharm; Bachelors of Pharmacy \\ PharmD; Doctor of Pharmacy \\ ISPOR; International Society for Pharmacoeconomics \\ and Outcomes Research \\ US: United States \\ UAE; United Arab Emirates \\ EPSA; European Pharmaceutical Student Association
}

\section{REFERENCES}

1. Townsend RJ. Postmarketing drug research and development. Drug IntellClin Pharm. 1987;21(1 Pt 2):134-6.

2. Bootman JL, Townsend RJ, McGhan WF. Principles of Pharmacoeconomics. $3^{\text {rd }}$ Edition. Cincinnati. Harvey Whitney. 2005.

3. PJ Online News. Pharmacoeconomics is vital to education. The Pharmaceutical Journal. 13 APR, 2002. Available at: http://www.pharmaceutical-journal.com/ pj-online-pharmacoeconomics-is-vital-to-education/20006485.article (Cited on 02-10-2015)

4. Mohammed SA. The role of pharmacoeconomics in formulary decision making in different hospitals in Riyadh, Saudi Arabia. Saudi Pharmaceutical Journal. 2011;19(1):51-6. Available at: http://www.sciencedirect.com/science/article/pii/ S1319016410000927 (Cited on 02-10-2015).

5. Rascati KL, Drummond MF, Annemans L, Davey PG. Education in pharmacoeconomics: an international multidisciplinary view. Pharmacoeconomics. 2004;22(3):139-47. Available at: http://www.ncbi.nlm. nih.gov/pubmed/14871162 (Cited on 02-10-2015).

6. Carter JT, Ebel JA. A comparison of pharmacoeconomics topics in journals and entry-level pharmacy degree curricula. Am J Pharm Educ.2001;65(1):30. Available at: http://search.proquest.com/openview/cc40ee0278195d254e3abb 69af26ba8b/1?pq-origsite=gscholar\&cbl=41120(Cited on 30-12-2015).

7. Rascati KL. Essentials of Pharmacoeconomics. $2^{\text {nd }}$ Edition. Philadelphia. Lippincott Williams and Wilkins. 2014

8. Makhinova T, Rascati KL. Pharmacoeconomics Education in US Colleges and Schools of Pharmacy. Am J Pharm Educ. 2013;77(7):145. Available at: http:// www.ncbi.nlm.nih.gov/pmc/articles/PMC3776899/ (Cited on 1/10/2015).

9. Reddy M,Rascati KL, Wahawisan J,Rascati M. Pharmacoeconomic Education in US Colleges and Schools of Pharmacy: An Update. Am J Pharm Educ. 2008;72(3):51. Available at: http://www.ncbi.nlm.nih.gov/pmc/articles/ PMC2508714/(Cited on 02/10/2015).

10. Rascati KL, Conner TM. Pharmacoeconomic Education in U.S. Schools of Pharmacy. American Journal of Pharmaceutical Education. 1998;62:167-9.

11. Nwokeji ED, Rascati KL. Pharmacoeconomic Education in Colleges of Pharmacy Outside of the United States. Am J Pharm Educ. 2005;69(3):52.

Indian Journal of Pharmacy Practice, Vol 9, Issue 3, Jul-Sep, 2016 
Available at: http://archive.ajpe.org/view.asp?art=aj690352\&pdf=yes(Cited on 02/10/2015).

12. Freitas GRM, Heineck I, Balbinotto G. Pharmacoeconomic Education in Brazilian Schools of Pharmacy. ISPOR $17^{\text {th }}$ Annual European Congress, 8-12 November, 2014. Amsterdam. Poster available at: http://www.ispor.org/ research_pdfs/48/pdffiles/PHP190.pdf (Cited on 1/10/2015).

13. Gafà M, Bilbija S, Martinova A, Bates I. Pharmacoeconomics: A view of EPSA member countries on issues related to awareness of the topic and the undergraduate curriculum. Pharmacy Education. 2002;2(4):171-175. Available at: http://discovery.ucl.ac.uk/1368452/ (Cited on 02-10-2015).

14. Nazlı Ş, Mehtap K, Çiğdem K,Wertheimer Albert. Pharmacoeconomics education and the knowledge levels of pharmacy students a in schools of pharmacy. Marmara Pharmaceutical Journal. 2014;18(1):5-12. Available at:http://ecc.isc.gov.ir/showJournal/26505/52636/696577(Cited on 1/10/2015).

15. Makhinova T, Makhinova EV, Rascati KL. Pharmacoeconomic Education for Pharmacy Students in the Russian Federation. Online poster presentation. Available at: https://www.utexas.edu/pharmacy/research/posters/ispor_eu12/ tatiana.pdf (Cited on 1/10/2015).

16. Zaliska O, Slabyy M, Tolubaiev M,Revyatskyy I. Development of education on Pharmacoeconomics in Ukraine. Journal of Health Policy and Outcomes Research. 2013;3(1):50-7.

17. Catić T, Skrbo S. Pharmacoeconomic Education for Pharmacy Students in Bosnia and Herzegovina. Mater Sociomed. 2013;25(4):282-5. Available at: http://www.ncbi.nlm.nih.gov/pmc/articles/PMC3914744/(Cited on 1/10/2015).

18. College of Pharmacy. Gulf Medical University. Available at: http://www.gmu. ac.ae/college-pharmacy/curriculum

19. College of Pharmacy. Al Ain University of Science and Technology. Available at: http://pharmacy.aau.ac.ae/en/

20. College of Pharmacy. Sharjah University. Available at: http://www.sharjah. ac.ae/en/academics/Colleges/Pharmacy/Pages/default.aspx

21. RAK College of Pharmaceutical Science. RAK Medical \& Health Sciences University. Available at: http://www.rakmhsu.com/pharmacy-college-in-dubai

22. Dubai College of Pharmacy. Available at: http://www.dpc.edu/

23. Ahmed M. Soliman, Mustafa Hussein,Abdulla M. Abdulhalim. Pharmacoeconomic Education in Egyptian Schools of Pharmacy. Am J Pharm Educ. 2013;77(3):57. Available at: http://www.ncbi.nlm.nih.gov/pmc/articles/ PMC3631732/(Cited on 1/10/2015).

24. PCl. Institutes offering Both PharmD and PharmD (Post Baccalaureate) Courses. Available at: http://www.pci.nic.in/CollegesCourses/Baccalaureate. aspx (Cited on 02-10-2015).

25. Khan MU, Ahmad A, Hussain K, Salam A, Hasnain Z, Patel I. The need for redesigned pharmacy practice courses in Pakistan: the perspectives of senior pharmacy students. J EducEval Health Prof. 2015;12:27. Available at: http:/l jeehp.org/DOlx.php?id=10.3352/jeehp.2015.12.27(Cited on 02-10-2015).

26. Kennedy-Martin T, Mitchell BD, Boye KS, Chen W, Curtis BH, Flynn JA, et al. The Health Technology Assessment Environment in Mainland China, Japan, South Korea, and Taiwan-Implications for the Evaluation of Diabetes Mellitus Therapies. Value in Health Regional Issues. 2014;3C:108-116.Available at: http://www.valuehealthregionalissues.com/article/S2212-1099(14)00016-8/ pdf(Cited on 02-10-2015).

27. Alefan Q, Allmam S, Mukattash T, Mhaidat N, Alabbadi I, Rascati KL. Pharmacoeconomics education in WHO Eastern Mediterranean region. Currents in Pharmacy Teaching and Learning. 2015;7(6):819-25. Available at:
http://www.sciencedirect.com/science/article/pii/S1877129715001021 (Cited on 30-12-2015).

28. Nwokeji ED, Rascati KL. Pharmacoeconomic Education in Colleges of Pharmacy Outside of the United States. Am J Pharm Educ. 2005;69(3):52. Available at: http://archive.ajpe.org/view.asp?art=aj690352\&pdf=yes(Cited on 02/10/2015).

29. WHO. Health Technology Assessment. Available at: http://www.who.int/ medical_devices/assessment/en/ (Cited on 02-10-2015).

30. INHATA. What is Health Technology Assessment. Available at: http://www. inahta.org/ (Cited on 02-10-2015).

31. Thomas D, Zachariah S, Reddy YP, Alvarez-Uria G. Development of pharmacoeconomics guidelines for India. PerspectClin Res. 2014;5:91. Available from: http://www.picronline.org/text.asp?2014/5/2/91/128030 (Cited on 02-10-2015).

32. ISPOR Pharmacoeconomic Guidelines around The World. http://www.ispor. org/PEguidelines/index.asp(Cited on 10-07-2015).

33. Merck. Public Policy Statement: Principles for Health Technology Assessment (HTA) and Comparative Effectiveness Research (CER). Jan 2011. Available at: https://www.merck.com/about/views-and-positions/health_technology _ assessment2011.pdf (Cited on 02-10-2015).

34. ISPOR. Health Technology Assessment in Evidence-Based Health Care Reimbursement Decisions Around the World: Lessons Learned. Value in Health 2009;12(Suppl. 2).Available at:https://www.ispor.org/HTAspecialissue/ index.asp(Cited on 02-10-2015).

35. Ahmad A, Patel I, Parimilakrishnan S, Mohanta GP, Chung H, Chang J. The role of pharmacoeconomics in current Indian healthcare system. Journal of Research in Pharmacy Practice. 2013;2(1):3-9. doi:10.4103/2279042X.114081.

36. Grauer DW, Lee J, Odom TD, et al., eds. Pharmacoeconomics and Outcomes: Applications for Patient Care: Case Studies. Kansas City: American College of Clinical Pharmacy, 2003. ISBN: 1-880401-79-7.

37. Kaplan RS, Haas DA. How not to cut health care costs. Harvard Business Review. November 2014. Available at: https://hbr.org/2014/11/how-not-to-cuthealth-care-costs (Cited on 15-10-2015).

38. Modiba WK, Nazer D, Wessels F. Pharmacoeconomics in a Health Care System in South Africa. ISPOR Connections. 2007;13(6). Available at: http:// www.ispor.org/news/articles/dec07/psa.asp (Cited on 15-10-2015).

39. Slejko JF, Libby AM, Nair KV, Valuck RJ, Campbell JD.Pharmacoeconomics and outcomes research degree-granting PhD programs in the United States. Research in Social and Administrative Pharmacy.2013;9(1):108-13.

40. Alvarez-Uria G, Thomas D, Zachariah S, Byram R, Kannan S. Cost-analysis of the WHO Essential Medicines List in A Resource-Limited Setting: Experience from A District Hospital in India. Journal of Clinical and Diagnostic Research. 2014;8(5):HM01-HM03. Available at: http://apps.who.int/medicinedocs/ documents/s21844en/s21844en.pdf (Cited on 15-10-2015).

41. Scomo ML, Kamal KM, Berdine HJ. A Required Course in the Development, Implementation, and Evaluation of Clinical Pharmacy Services. Am J Pharm Educ. 2008;72(5):109.Available at: http://archive.ajpe.org/view. asp?art=aj7205109\&pdf=yes(Cited on 15-10-2015).

42. DiPiro JT, Talbert RL, Yee GC, Matzke GR, Wells BG, and Posey LM. Pharmacothrapy: a pathophysiologic approach. $9^{\text {th }}$ Edition. New York. McGraw Hill, 2014; Available at: http://accesspharmacy.mhmedical.com/book. aspx?bookid=689 (Cited on 03-10-2015). 